\title{
Diet of Chukar Partridge Alectoris chukar (Gray): Histological analysis of the droppings
}

\author{
M. S. Bisht*1 \\ ${ }^{1}$ Department of Zoology, H N B Garhwal University (A Central University), Campus Pauri, Uttrakhand, India - 246001 \\ *Corresponding author: bisht_msgwl@rediffmail.com
}

Received: 5.8.2021; Revised: 12.11.2021; Accepted: 13.11.2021

CSociety for Himalayan Action Research and Development

\begin{abstract}
Undigested remains from droppings of Chukar partridge Alectoris chukar (Gray) were examined under the microscope for qualitative and quantitative information on the food and feeding habits of this popular sport bird. Findings suggested that the Chukar partridge feed both the plants and animals along with grits throughout the year. The vegetative parts was comprised by overall $87.73 \pm 12.31 \%$ of faecal remains and represented by total 24 species of plants, belonging to 13 families while non-vegetative part was $9.36 \pm 2.46 \%$ and represented by hard body parts of 8 Orders of arthropods. Other than plants and animals, average $2.84 \pm 1.17 \%$ grits was also recorded from undigested faecal remains. The leaves, roots and seeds of plants like Saccharum, Brachiaria, Chloris, Echinochloa, Oryza, Apluda (of the family Poaceae) and seeds of Cajanus, Vigna and Glycine (family Fabaceae), and grasshoppers (order - Dissoptera) and flies (order - Diptera) are identified as major components of the diet of Chukar partridge.
\end{abstract}

Key words: Histological analysis, Faeces, Undigested, Chukar partridge.

\section{Introduction}

Chukar partridge Alectoris chukar (Gray) is a most popular game bird of the hillside countries. Its total sixteen sub-species have been known to occur in different parts of the Europe and South Asia enjoying from sea level to $5000 \mathrm{~m}$. asl (Hume and Marshall 1879, Ali and Ripley 1983 and Madge and McGowan 2002). As a game species, it has been introduced in many countries like the North America, South Africa, Hawaii, New Zealand and St. Helena Island etc (Galberath and Moreland 1953, Christensen 1996 and Watson 1966). In the Indian sub-continent, Chukar partridge is found in Punjab, Jammu and Kashmir, Himachal Pradesh and Uttrakhand and known as "Chakor" in vernacular language (Ali and Ripley 1983, Bisht and Kukreti 2010). In the hills of Uttrakhand Chukar partridge is also considered as a pest species because large flocks of this bird are some time seen in freshly sown crop fields.

Information on the feeding habits of this bird is very little till date and based on the field observation, made by a simple visual method in which feeding birds are observed by binoculars (Green, 1984 and Cole et al., 1995, Christensen et al. 1996). Previous studies suggested that the Chukar partridge feeds on leaves of grasses, fruits and seeds of wild forbs, fallen seeds from crop fields etc. Histological analysis of the droppings or faecal pellets is one of the most important and reliable method of study of the food and feeding habits of any wild animals including the birds. Because this method does not need any sacrifice of animals or a painful regurgitation of food. Many avian scientists like Eastman and Jenkins (1970), Butterfield and Coulson (1975), Younzon and Lelliot (1981), Marti (1982), Bhandary et al 
(1986) and Phurailatpum et al (2005) has been As a good correlation had established a very good correlation between undigested faecal remains and diet of many game birds. To obtain the authentic information on the diet and also to

\section{Material and Methods}

\section{Chukar partridge Alectoris chukar (Order-} Galliformes, Family-Phasianidae) is a bird of the open hill-side countries. It inhabits open, arid, rugged slopes covered with scattered trees (Pinus roxburghii, Abies), scrubs (Berberis, Rubus, Rhus, Rosa, etc) and long grasses like Saccharum, Chloris, Heteropogon. In the present study, droppings of Chukar were collected from the south facing slopes at $1950 \mathrm{~m}$ altitude in the district Pauri Garhwal, Uttrakhand ( $30^{\circ} 15^{\prime} \mathrm{N}$ and $\left.78^{\circ} 30^{\prime}\right)$. Every month, fresh faecal pellets were collected from feeding and roosting habitats in the sealed plastic bags, brought to the laboratory, and dried in a oven at $60^{\circ} \mathrm{C}$ temperature for 30 minutes to remove the residual moisture. Once weighed, the pellets were stored in air dried polythene bags. For histological analysis, 10-12 dried pellets were soaked in water for 3 to 5 days; large pieces were broken by using the dissecting needle and sieved through a $212 \mu \mathrm{m}$ brass mesh (Moreby 1993 and Ralph et al, 1985). The material retained was evenly distributed on a $10 \mathrm{~cm}$ Petri dish scored with $1 \mathrm{~cm}^{2}$ grids and examined under a polarized light microscope. The photographs of each undigested food fragments were taken at 50x and 100x magnifications and confirm a pest habit of Chukar partridge histological analysis of the droppings/faecal pellets were carried out in district Pauri Garhwal, Uttrakhand.

identified with the help of text books (Sharp 1968a \& b, Warburtan 1968), photographic aids (Satakopan 1972, Ralph et al. 1985; Moreby 1993). The reference slides were also prepared from the herbarium and insects samples collected by using sweep net and pitfall traps from study area for easy identification of food elements. The frequency occurrence of fragments of each species/family/order) and the percentage of field of view covered by it were recorded. Then undigested organic material of petri dish was washed, air dried and weighed for dry-weight of plant, nonvegetative food and grits.

\section{Results and Discussion}

In the histological study of undigested remains from the droppings of Chukar partridge both plants and animals parts along with grits were observed. The plants part constitutes a major portion of faecal remains as average $87.73 \pm 4.31 \%$ of dry weight ( Table 1), and exhibit a seasonal variation with maximum value during September $91.57 \pm 2.78 \%$ (of dry weight) and minimum $84.66 \pm 6.43 \%$ during April. In the non-vegetative matter, hard body parts of arthropods were recorded with overall value $9.36 \pm 1.46 \%$ (ranging from $13.33 \pm 1.66 \%$ during April to $6.60 \pm 1.05 \%$ during September). The fine 
organic matter (F.O.M) along with grits was recorded with overall value $2.84 \pm 1.17 \%$ of mean dry weight (ranging from $6.21 \pm 1.73 \%$ in August to $1.02 \pm 0.66 \%$ in the month of March).

a) Plant or vegetative diet: From the droppings of Chukar partridge, fragments of the leaves, flowers, seeds, fruits, roots, tubers etc of more than 24 plant species belonging to 13 families namely Anacardiaceae, Asteraceae, Berberidaceae, Cruciferae, Cyperaceae, Fabaceae, Malvaceae, Menispermaceae, Plumbaginaceae, Poaceae, Rosaceae, Saxifragaceae, and Utricaceae were identified (Table 2, Plate 1). Parts of the some plants like Indocourtoisia, Cajanus, Rumex, Saccharum, Brachalaria, Rubus, Rosa and Berginia were encountered consistently in all the months and seasons. All the plant families except Malvaceae were represented in the diet during the winter season (November to February) when some of the plants were recorded with a very high frequency more than fifty percent occurrence such as Brassica campestris (66.55 $\pm 7.42 \%)$, Boehmeria

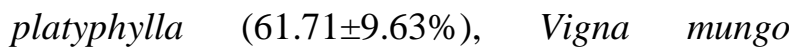
(51.88 $\pm 9.08 \%)$, Glycine $\max (42.89 \pm 6.73 \%)$, Indocourtoisia cyperoides (51.82 $\pm 3.60 \%)$, Rumex hastatus $(50.12 \pm 6.25 \%)$ etc. In the summer season (March to June) also, all families were encountered in the faecal contents. The grasses like Chloris dolichostachya and Heteropogon contortus were recorded with hundred percent frequency occurrence followed by wheat grains (Triticum aestivum) (54.52 $\pm 2.86 \%), \quad$ Oryza sativa (50.42 $\pm 11.27 \%), \quad$ Echinochloa colona (49.79 $\pm 2.57 \%)$, Berberis asiatica $(40.74 \pm 8.40 \%)$ and Berginia ciliata $(40.22 \pm 8.50 \%)$. During the monsoon period (August to October), again all families except Cruciferae were encountered in the faeces. The plants with high frequencies were identified as Hibiscus trionum $(80.53 \pm 12.67 \%)$, Artimisia nilagirica $(75.87 \pm 1.71 \%)$, Stephania

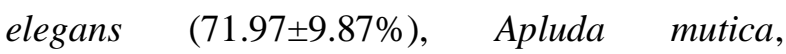
$(57.36 \pm 3.79 \%)$ Rhus parviflora (54.72 $\pm 5.23 \%)$, Echinochloa colona $(50.20 \pm 6.93 \%)$ and Oryza sativa $(49.57 \pm 9.22 \%)$.

b) Non-vegetative diet: The fragments of hard body parts like mandibles, maxillae, antennae, wings, legs and elytra of insects (Arthropods) belonging to eight orders namely Araneae, Diptera, Dissoptera, Heteroptera, Hymenoptera, Isoptera, Lepidoptera and Zoraptera were identified from the faecal remains of Chukar partridge (Table 3, Plate 2).

During the winter, body parts of termites (Isoptera) were observed with highest value $(42.41 \pm 6.24 \%)$, followed by the Cocinella (Zoraptera) $41.34 \pm 3.12 \%$, spiders (Araneae) 40.55 $\pm 4.35 \%$, butterflies (Lepidoptera, 33.10 $\pm 1.10 \%$ ), ants Hymenoptera $\quad(32.92 \pm 3.31 \%), \quad$ Heteroptera $(31.42 \pm 6.97 \%)$ and flies (Diptera, 27.90 $\pm 2.27 \%)$. Grasshoppers (Dissoptera) were not recorded in any month of the winter season (pre breeding period).

Table 1: Mean dry weight composition of the droppings of Chukar partridge. 


\begin{tabular}{|c|c|c|c|c|}
\hline \multirow[t]{2}{*}{ Month } & \multirow[t]{2}{*}{ Faecal dry weight (g) } & \multicolumn{2}{|c|}{$\%$ dry weight composition } & \multirow[b]{2}{*}{ F.o.m+Grits } \\
\hline & & Vegetative parts & Non-vegetative parts & \\
\hline July, 2008(9) & $0.89 \pm 0.05$ & $84.76 \pm 4.21$ & $10.83 \pm 0.83$ & $4.41 \pm 2.23$ \\
\hline August(10) & $1.00 \pm 0.09$ & $85.46 \pm 3.64$ & $7.33 \pm 1.80$ & $6.21 \pm 1.73$ \\
\hline September $(8)$ & $1.45 \pm 0.11$ & $91.57 \pm 2.78$ & $6.66 \pm 1.05$ & $1.77 \pm 0.37$ \\
\hline October(7) & $1.11 \pm 0.04$ & $88.78 \pm 4.57$ & $7.12 \pm 0.91$ & $3.10 \pm 1.32$ \\
\hline November(6) & $1.03 \pm 0.04$ & $86.66 \pm 4.37$ & $8.33 \pm 1.66$ & $5.01 \pm 1.83$ \\
\hline December(7) & $1.30 \pm 0.02$ & $89.20 \pm 7.47$ & $7.00 \pm 1.22$ & $3.80 \pm 0.82$ \\
\hline January, 2009(7) & $0.80 \pm 0.05$ & $89.83 \pm 1.23$ & $8.00 \pm 1.22$ & $2.20 \pm 0.94$ \\
\hline February(9) & $1.62 \pm 0.07$ & $88.86 \pm 2.24$ & $9.16 \pm 2.27$ & $1.98 \pm 0.57$ \\
\hline $\operatorname{March}(11)$ & $1.04 \pm 0.07$ & $86.87 \pm 4.68$ & $11.66 \pm 1.66$ & $1.02 \pm 0.66$ \\
\hline April(10) & $1.16 \pm 0.04$ & $84.66 \pm 6.43$ & $13.33 \pm 1.66$ & $2.01 \pm 1.12$ \\
\hline May(12) & $0.89 \pm 0.03$ & $88.66 \pm 5.43$ & $10.00 \pm 2.23$ & $1.34 \pm 0.63$ \\
\hline June(8) & $1.63 \pm 0.25$ & $87.66 \pm 4.70$ & $11.00 \pm 1.00$ & $1.34 \pm 0.61$ \\
\hline Annual(104) & $1.15 \pm 0.05$ & $87.73 \pm 4.31$ & $9.36 \pm 1.46$ & $2.84 \pm 1.17$ \\
\hline
\end{tabular}

Figure in the parenthesis are number of samples analyzed.

In the summer season, fragments of the body parts of all 8 Orders were encountered in the faeces, with highest frequency occurrence of grasshoppers $(65.79 \pm 10.64 \%)$, followed by Heteroptera (49.50 $\pm 2.85 \%)$, butterflies $(45.10 \pm 6.02 \%)$, Coccinella $(39.05 \pm 3.23 \%)$, spiders $(37.25 \pm 2.0 \%)$ and etc. In the monsoon season (July to October), all Orders of arthropods were represented in the faeces. Diptera (flies) were recorded with highest frequency occurrence $(51.37 \pm 5.18 \%)$, followed by termites $(42.24 \pm 5.43 \%), \quad$ grasshoppers $(34.20 \pm 0.89 \%)$, ants $(26.35 \pm 6.32 \%)$, spiders $(22.19 \pm 2.08 \%)$, butterflies $(21.79 \pm 3.87 \%)$ and Heteroptera $(19.07 \pm 1.45 \%)$. Unidentified body parts of arthropods were recorded throughout the year in range of $30.91 \%$ (summer season) to $34.97 \pm \%$ (winter months). Findings of the present study based on the histological analysis of droppings for the first time suggest that the Chukar partridge Alectoris chukar is an opportunistic bird, feed all types of vegetarian and non vegetarian food including the forbs seeds, grasses, fruits, crop grains, insects etc. But presence of a high amount of plants parts (dry weight) in faecal remains in all months and seasons revealed that - i) the Chukar is a more vegetarian bird and ii) diet selection is related to the availability of food in nature. For example the annual plants like Rhus, Berberis were eaten in all seasons. Presence of hard body parts of arthropods (mostly insects) in undigested remains does not mean that the Chukar partridges not feed on the soft bodied animals like worms, grubs, larvae, small reptiles, snails etc. Christensen (1996) had suggested that the Chukar partridge also feed on worms, snails, small reptiles etc.

Table 2: Frequency occurrence of the plant parts in faecal contents of Chukar partridge. 
Vol. 16(3), (2021), 201-208

Families/Plants

Anacardiaceae

Rhus parviflora

Artimisia nilagirica

Asteraceae

Aster albescens

Berberidaceae

Berberis asiaticus

Cruciferae

Brassica campestris

Cyperaceae

Indocourtoisia cyperoides

Fabaceae

Cajanus volubilis

Vigna mungo

Glycine max

Malvaceae

Hibiscus trionum

Meninspermaceae

Stephania elegans

\section{Plumbaginaceae}

Rumex hastatus

Poaceae

Saccharum rufipilum

Brachiaria villosa

Triticum aestivum

Chloris

Dolichostachya

Heteropogon contortus

Apluda mutica

Echinochloa colona

Oryza sativa

Rosaceae

Rubus ellipticus

Rosa brunonii

Saxifragaceae

Bergenia ciliate

Utricaceae

Boehmeria platyphylla
Parts used

Frequency occurrence (in \%)

\begin{tabular}{lll}
\hline Winter & Summer & Monsoon \\
\hline $28.92 \pm 3.98$ & $16.35 \pm 2.06$ & $54.72 \pm 5.23$ \\
$15.63 \pm 1.50$ & $8.48 \pm 2.90$ & $75.87 \pm 1.71$
\end{tabular}

Leaves \& roots

Leaves \& roots

$30.61 \pm 4.09$

$34.21 \pm 7.62$

$35.17 \pm 3.39$

Flowers \& fruits

$31.86 \pm 1.78$

$40.74 \pm 8.40$

$27.38 \pm 3.42$

Leaves, flowers \& seeds

$66.55 \pm 7.42$

$33.45 \pm 3.91$

0.0

Leaves

$51.82 \pm 3.60$

$33.19 \pm 4.73$

$14.25 \pm 2.11$

Fruits, seeds \& roots

$31.87 \pm 6.03$

$35.85 \pm 5.91$

$32.27 \pm 2.17$

Seeds

$51.88 \pm 9.08$

$10.51 \pm 1.55$

$37.59 \pm 3.94$

Seeds

$42.89 \pm 6.73$

$28.47 \pm 3.11$

$28.62 \pm 2.98$

0.0

$19.46 \pm 3.45$

$80.53 \pm 12.67$

Seeds

$19.6 \pm 1.67$

$8.40 \pm 1.90$

$71.97 \pm 9.87$

Leaves \& fruits

$50.12 \pm 6.25$

$37.74 \pm 3.97$

$13.30 \pm 5.60$

Leaves \& seeds

$32.11 \pm 0.96$

$34.41 \pm 1.01$

$33.46 \pm 5.43$

Leaves \& roots

$33.07 \pm 3.91$

$35.38 \pm 2.75$

$31.54 \pm 1.68$

Leaves \& grains

$45.47 \pm 6.62$

$54.52 \pm 2.86$

0.0

Leaves \& roots

0.0

$100.00 \pm 0.0$

0.0

Leaves \& roots

0.0

$100.0 \pm 0.0$

0.0

Leaves \& seeds

$42.63 \pm 7.64$

0.0

$57.36 \pm 3.79$

Leaves \& seeds

0.0

$49.79 \pm 2.57$

$50.20 \pm 6.93$

Seeds

0.0

$50.42 \pm 11.27$

$49.57 \pm 9.22$

Leaves, flowers \& fruits

$41.17 \pm 5.68$

$18.82 \pm 3.21$

$30.44 \pm 1.11$

Leaves, flowers \& fruits

$39.01 \pm 1.96$

$30.51 \pm 5.41$

$28.97 \pm 2.89$

Rhizomes

$33.41 \pm 1.09$

$40.22 \pm 8.50$

$26.35 \pm 2.67$

Leaves \& seeds

$61.71 \pm 9.63$

$12.76 \pm 1.07$

$25.52 \pm 3.57$ 


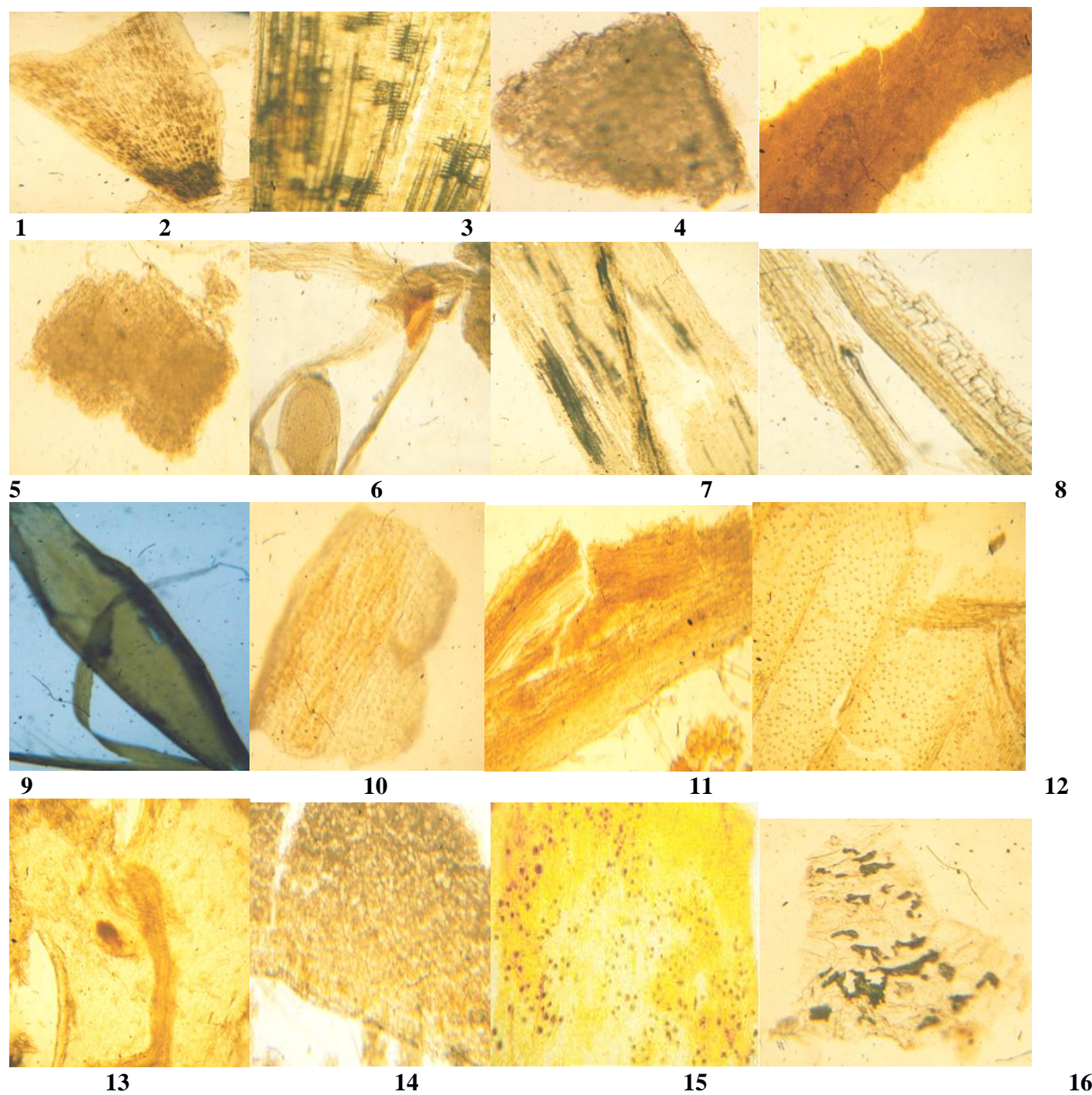

Fig Plate I. Plant parts encountered in the faeces of Chukar partridge. 1. Seed of Echinochloa colona, 2. Seed of Oryza sativa, 3. Macrotyloma uniflorum seed part, 4. Vigna mungo seed part, 5. Seed part of Glycin max, 6. Flower part of Brassica rapa campestris, 7. leaf part of Alpuda mutica, 8. Flower part of Rosa brunonaii, 9. Leaf part of Chlorisdolichostachya, 10. Fruit parts of Berginia ciliata, 11. Leaf part of Aster albescens, 12. Fruit part of Cajanus sacrabcoides, 13. Fruit part of Berberis asitata, 14. Leaf part of Inocourtosia cyperoides, 15. stone cell in fruit of Rubus, 16. Leaf part of Rumax.

This diet selection of animals depends upon availability of food in habitats. For example the body parts of certain grasses (Hisbiscus, Chloris, Heteropogon) as well as grasshoppers were not encountered in faeces during the winter season because they were also not available in the habitat during this period. During the summer and monsoon seasons, consumption of grasshoppers and flies was found with a high frequency when their abundance was quite well. 


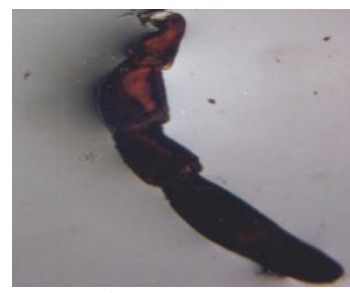

1

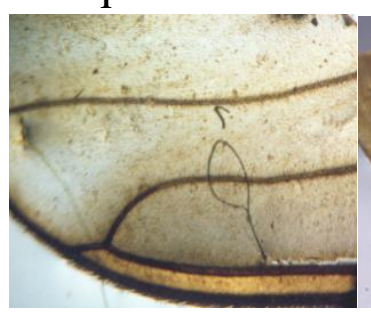

5

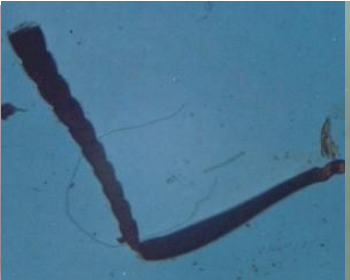

2

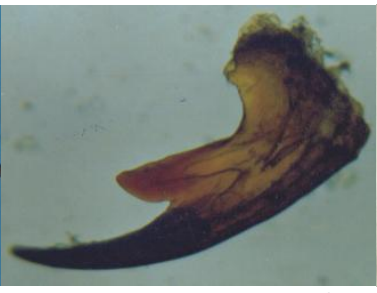

3

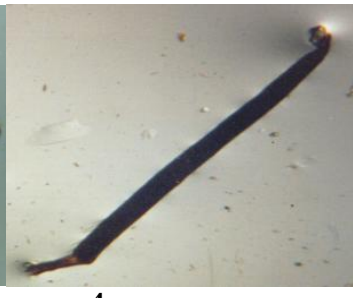

4

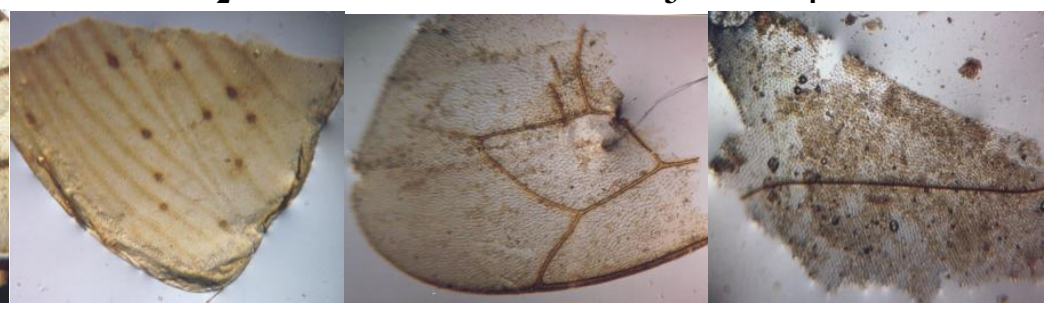

6 7

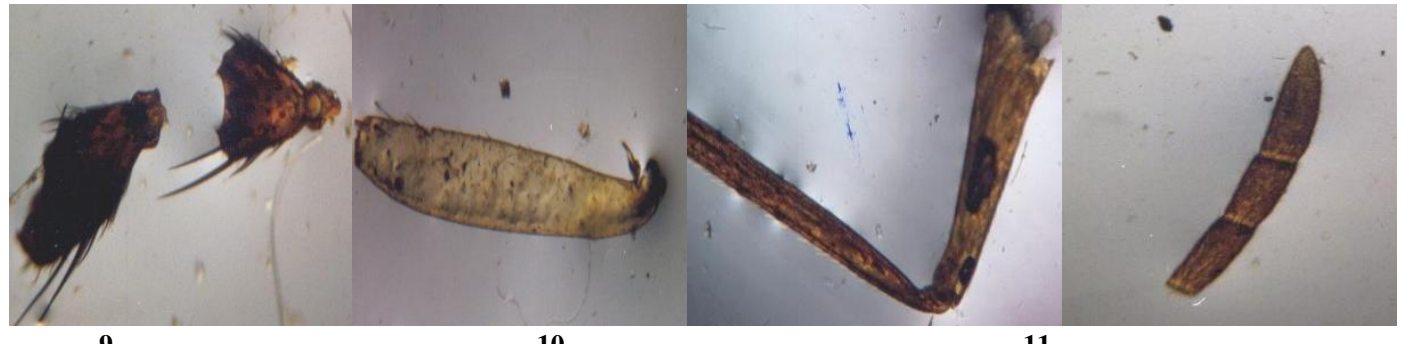

8

9

10

11 12

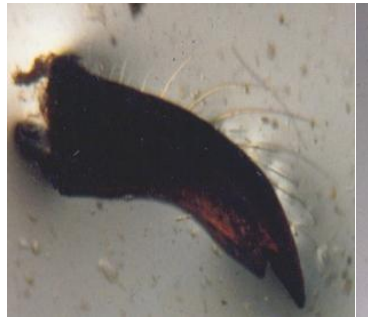

13

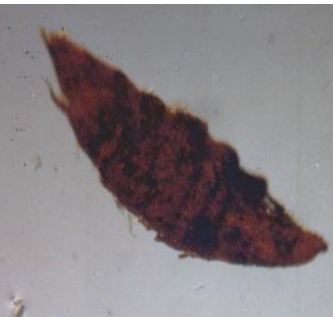

14

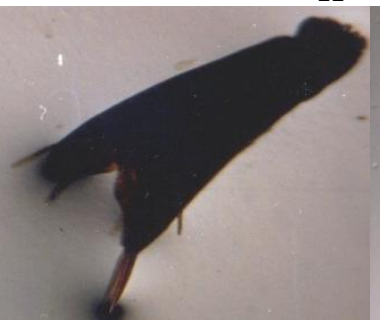

15

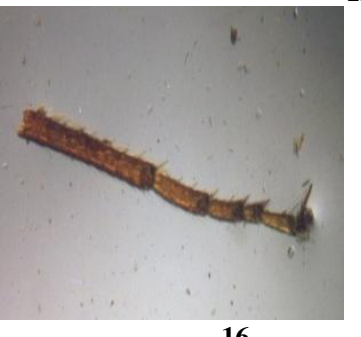

Fig Plate II. Arthropod parts encountered in the faeces of Chukar partridge. 1. Spider labium, 2. Coleopteran antenna, 3. Staphylened mandible, 4. Mouth part of Micropteryx aruncella, 5. Heteropteran wing, 6. Dipteran wing, 7. Coccinella hind wing, 8. Wing of flies, 9. Mandible of micropterygidae, 10. Dipteran middle leg, 11. Antenna of Grasshopper, 12. Dipteran antenna 13. Scarabid larva of butterflies, 14. Lepidopteran larva, 15. Termite mandible and 16. Ant hind leg.

Table 3: Frequency occurrence of the arthropods body parts in faecal contents of Chukar partridge.

\section{Arthropods /Orders \\ Araneae (Spiders) \\ Diptera (Flies) \\ Dissoptera (Grasshoppers) \\ Heteroptera \\ (Spilostethus pondurus) \\ Hymenoptera (Ants) \\ Isoptera (Termites) \\ Lepidoptera (Butterflies) \\ Zoraoptera (Coccinella) \\ Unidentified}

\section{Frequency occurrence (in \%)}

$\begin{array}{lll}\text { Winter } & \text { Summer } & \text { Monsoon } \\ 40.55 \pm 4.35 & 37.25 \pm 2.00 & 22.19 \pm 2.08 \\ 27.90 \pm 2.27 & 20.73 \pm 3.90 & 51.37 \pm 5.18 \\ 0.0 & 65.79 \pm 10.64 & 34.20 \pm 0.89 \\ & & \\ 31.42 \pm 5.97 & 40.72 \pm 2.85 & 26.35 \pm 1.45 \\ 32.92 \pm 3.31 & 15.34 \pm 2.44 & 42.24 \pm 6.32 \\ 42.21 \pm 6.24 & 15.34 \pm 4.02 & 42.24 \pm 5.43 \\ 33.10 \pm 1.10 & 45.10 \pm 6.02 & 21.79 \pm 3.87 \\ 41.34 \pm 3.12 & 39.05 \pm 3.23 & 19.59 \pm 1.50 \\ 34.11 \pm 4,09 & 30.91 \pm 2.48 & 34.97 \pm 2.10\end{array}$


Importance of protein rich food during breeding and post breeding (during summer and monsoon times) in many game birds has been reported by many field biologists like Ford and Middleton (1938), Vickerman and Bryan (1979), Southwood and Cross (1969), Bhandary et al. (1986), Kaul (1990) and Phurailatpum et al. (2005). Presence of the fragments of grains of Triticum, Oryza, Glycine, Vigna and Brassica suggest the grainivorous habit of Chukar partridge but during the study this bird was never observed feeding on the standing crops (Bisht and Kukreti 2010). Occasional sighting of Chukars on freshly sown crop fields do not confirms its pest habit. Christensen (1996) and Weaver and Haskel (1967) also reported that the Chukar partridge feed on the fallen grains only.

\section{Acknowledgment}

Author is thankful to the Uttarakhand Council of Science and Technology, Dehradun for the financial assistance as a research grant no. UCS\&R\&D/LS-68/07-08.

\section{References}

Ali S and Ripley SD (1983) Handbook of birds of India and Pakistan. Compact Edition. Oxford University Press. New Delhi

Bhandary HR, Schmintz SD and Picozzi N (1986) Autumn foods of forest pheasants of Pipar, Central Nepal. J. World Pheasant Association. 11:29-33.
Bisht M S and Kukreti M (2010) Breeding behaviour of Chukar partridge Alectoris chukar in Garhwal Himalaya, Uttarakhand. Indian J. of Forestry, 33(2): 155-159.

Butterfield J and Coulson J C (1975) Insect food of adult Red grouse Lagopus lagopus scoticus (Lath.). J. Animal Ecol. 44:601-608.

Christensen GC (1996) Chukar Alectoris chukar,The birds of North America, Philedelphia. The Academy of Natural Sciences of Philadelphia. Ed. Poole, F. G. Pp.1-20.

Cole FA, Loope JM and Wood C (1995) Conservation implication of introduced game birds in high elevation Hawaiian scrubland. Conservation Biology. 9:306-313.

Eastman DS and Jenkins D (1970) Comparative food habits of Red grouse in northeast Scotland using fecal analysis. J. Wildlife Management. 34: 612-620.

Ford J, Chitty H and Middleton AD (1938) The food of partridge chicks (Perdix perdix) in Great Britain. J. Animal Ecology. 7:251-265.

Galbreath DS and Moreland R (1953) The Chukar partridge in Washington. Biology Bulletin no. 11. Washington Department of Game, Olympia, Washington, USA.

Green RE (1984) Feeding ecology and survival of partridge chicks (Alectoris rufa and Perdix perdix) on arable farmland in east Auglia. $J$. Applied Ecology. 21: 817-830.

Hume AO and Marshall CHT (1879) The game birds of India, Pakistan, Bangaladesh, Burma 
and Sri Lanka. Bhavana Books \& Prints $\left(2^{\text {nd }}\right.$ reprint, 1995), New Delhi. Vol. II:33-43.

Kaul R (1990) Invertebrate abundance, monsoon commencement and hatching time in the Cheer pheasant. In Hill, D. A. Garson, P. J. and Jenkins, D. (Eds.), Pheasants in Asia. World Pheasant Association, Reading, U.K. Pp. 218-219.

Madge S and Macgowan P (2002) Pheasants, partridges and grouse. Christopher Helm, London.

Marti C (1982) Accuracy of faecal analysis for identifying foods of Black grouse. J. Wildlife Management. 46: 773-777.

Moreby SJ (1988) An aid in the identification of arthropod fragments in the faeces of game bird, chicks (Galliformes). Ibis. 130: 519-526.

Moreby SJ (1993) Faecal analysis as a method for determining the invertebrate diet of Galliformes and its use in helping to assess food availability. In D. Jenkins (Ed.). Pheasants in Asia, 1992. World Pheasant Association. Pp.67-72.

Oakleaf RJ and Robertson JH (1971) Fall food items utilized by Chukars in Kashmir, India. $J$. Wildlife management.35: 395-397.

Phurliatpam S, Kathait BS; Bisht MS and Bisht BS (2005) Feeding biology of Cheer pheasant Catreus wallichii: Faecal analysis of its arthropods diet. Proc. of the $3^{\text {rd }}$ Inter. Galliformes Symposium. In: Fuller RA and Browne SJ (Eds.) World Pheasant Association, UK. Pp.180-187.

Ralph CP, Nagata SE and Ralph CJ (1985)
Analysis of droppings to describe diets of small birds. J. Field Ornithology. 56: 165-174.

Satakopan S (1972) Keys to the identification of plant remains in animal dropping. J. Bombay Nat. Hist. Soc. 60(1):139-150.

Sharp D (1968a) Insect part I. In Harmer \& Shipley (eds.). The Cambridge Natural History. Codicote, England. Wheldon \& Wesley, Ltd. Vol. V.

Sharp D (1968b) Insect part II. In Harmer \& Shipley (eds.). The Cambridge Natural History. Codicote, England. Wheldon \& Wesley, Ltd. Vol. VI.

Southwood TT and Cross DJ (1969) The ecology of partridge III. Breeding success and the abundance of insects in natural habitats, $J$. Animal Ecology. 38:497-509.

Vikeramn GP and Bryan MO (1979) Partridge and insects. Game Conser.Annual Rev.. 10:35-43. Warburton C (1968) Scorpion, spiders, mites, ticks. In Harmer and Sipley (Eds.) The Cambridge Natural History, Codicote, England.

Watson GE (1966) The Chukar partridge (Aves) of St. Helena Island, South Atlantic Ocean. Proc. Biol.l Soc. Washington. 79:179-182.

Weaver HR and Haskel WL (1967) Some fall foods of Nevada Chukar partridge. $J$ Wildlife management. 31:582-584.

Yonzon PB and Lelliot AD (1981) Food habits and feeding of Himalayan pheasants. J. Nat. Hist. Museum (Kathmandu). 5: 93-98. 